\title{
Korupce
}

\section{Václav Tuma}

Vedoucí práce: doc. Dr. JUDr. Jan Hejda

\section{1. Úvod}

Slovo korupce pochází z latinského názvu „rumpere“ či „corrumpere“, což znamená zlomit, přetrhnout, kazit, oslabit, znetvořit nebo podplatit. Korupce znamená zneužití postavení, funkce k osobnímu prospěchu v oblasti politiky, veřejné správy, hospodářství. Může mít formu drobné korupce, ale často mívá podobu velké korupční skupiny, která může mít i mezinárodní rozsah a může být jak neorganizovaná, tak formálně organizovaná. Vyznačuje se podplácením, úplatky, vydíráním a zastrašováním. Další podobou jsou různá privilegia, neoprávněné př́ijmy a jejich vyžadování, udělování prŕizně, protežování atd. Politická korupce v konečném stádiu může vést k tzv. kleptokracii. Jedná se o vládu zlodějů a loupežníků (podle doslovného překladu), kdy už odpadá i předstírání poctivosti a upř́mnosti před veřejností.

Polistopadový politik Fedor Gál na adresu korupce prohlásil: „Mají-li mít slova o svobodném trhu, demokracii a svobodě nějaký smysl, pak je zapotřebí vědět, že korupce je jed, který ničí právě to, co by mělo tvořit obsah těchto slov. Důsledky mohou být fatální - z demokracie a svobody se stane luxusní zboží přístupné jenom těm, kteří mají peníze a nemají skrupule.“

Zajímavý pohled na korupci říká, že korupční potenciál dřímá takřka v každém z nás a úplatný je asi každý člověk, záleží jen na výši nabízené částky. Úplatek je často považován za klíč, který otevírá každé dveře. Korupce není žádný novodobý nebo ryze český fenomén, nýbrž se vyskytuje na celém světě už po staletí. Její prvky nalezneme snad ve všech typech státních útvarů a politických zařízení a ve všech sférách státní správy. Protikorupční opatření obsahoval již Chammurapiho zákoník a prameny práva $\mathrm{v}$ antickém Řecku a Rímě.

Lidé v různých sociálních prostředích mají různý názor na to, co korupce je a co není. Také národnostní odlišnosti hrají v chápání korupce vekou roli. Co je u nás běžná praxe a legální činnost, je v zahraničí trestně stíháno jako korupce. V České republice se pod slovem korupce rozumí úplatkářství a lidé u nás považují tato dvě slova za dokonalá synonyma. V západní Evropě se do pojmu korupce zahrnují i takové jevy jako např. vydírání ze strany úředníků nebo politiků, zneuživání postavení a pravomocí, zpronevěra veřejných prostředků, braní provize z veřejných zakázek, zvýhodňování známých a př́ibuzných, tj. klientelismus a nepotismus.

\section{Korupce a její stádia}

\subsection{Stádium náhodné korupce}

Ve stádiu náhodné korupce ještě nedochází ke vzniku a šíření ustáleného souboru korupčních norem. Obyvatelstvo i elity obecně preferují dobrou pověst před krátkodobým fi- 
nančním ziskem. Základním předpokladem pro setrvávání korupce v tomto stádiu je fungující kontrolní mechanismus. Riziko odhalení korupčního jednání je velké a výjimečné prŕípady korupce vzbuzují dostatečně silnou vlnu vzdoru. Odhalení zkorumpovaní jedinci jsou veřejně pranýřrování, stíháni a nakonec podle platných zákonů odsouzeni.

\subsection{Stadium spontánně regulované korupce}

V př́ípadě selhání kontrolních mechanismů přestává být korupce fenoménem roztroušených ostrůvků deviantního chování či izolovaných patologických organizačních struktur a z výjimek se postupně stává pravidlo. V tomto stadiu živelně vznikají určité korupční normy a stávají se „nakažlivé“. Korupce se stává masovým fenoménem a může dosahovat masových rozměrů.

\subsection{Stadium organizované korupce}

Korupce sama o sobě se stává soutěží a vyhrává ten, kdo je schopen vyřadit ze hry konkurenty, zvýšit korupční zisky a pojistit korupční rizika. Korupce se mění v organizovaný zločin a bere na sebe podobu vydírání. Korupce se institucionalizuje a prorůstá do nejvyšších míst státní správy a politiky. S institucionalizací pronikají do korupčního systému netržní prvky, které vyústí ve vznik korupčních monopolů.

\subsection{Stadium systémové korupce}

Korupce v tomto stadiu dosahuje svého vrcholu a je natolik srostlá se státní správou a politikou, že bez ní tyto instituce nemohou fungovat. Ve státní správě vznikají nová oddělení a komise, jejichž skrytým, ale pravým účelem je vyžadování úplatků. Vznikají organizace zabývající se zkorumpováním veřejných činitelů. Politici a vysocí státní úředníci sami organizují korupci a vybírají podíly na úplatcích. Státní instituce a úrady se neformálně mění v soukromé firmy maximalizující zisky šéfů. Vzniká korupční stát, kdy je korupce garantovaná a podporovaná státem.

\section{Př́ičiny vzniku a důsledky korupčního chování}

Obecně se dá říci, že základním zdrojem korupce je lidská touha po zisku či osobním úspěchu. Př́ležitosti pro korupci vznikají všude tam, kde jsou veřejným činitelům svěřovány pravomoci. Nejlepší korupční př́ležitosti ale poskytují případy, když činitelé mohou skrytě a neomezeně rozhodovat o rozdělování požadovaných statků. Zjednodušeně se dá také říci, že čím více administrativy, státních regulací a čím vrstevnatější je systém vyřizování záležitostí občanů, tím více existuje možností pro skryté rozhodování i korupčních př́ležitostí. Samozřejmě záleží nejen na organizačním uspořádání, ale i na osobních vlastnostech úředníků a žadatelů.

\section{Důležitou roli hrají různé korupční podněty:}

- Sankce - nedokonalost zákonů postihujících korupci a nízké sazby za jejich porušování vedou ke zvyšování pravděpodobnosti korupčního chování.

- Výše úplatku - hraje roli při eliminaci korupčního vzdoru. Od určité výše se těžko odolává i těm nejpoctivějším.

- Byrokratická kultura - např́iklad absence etického kodexu výkonu funkce veřejného činitele vede $\mathrm{k}$ nedostatku loajality ke svému úřadu a nedostatečnému pocitu poslání. Korupci podporuje též nerozvinutá či zanedbávaná byrokratická kultura. 
- Normy - v prŕípadě, že systém norem a pravidel výkonu funkce veřejného činitele je nejasný, zvyšuje se prostor i motivace ke korupčnímu chování.

- Kontrola - nerozvinutý a zanedbávaný sytém kontroly způsobuje omezení rizika odhalení korupce a zvyšuje motivaci ke korupčnímu chování.

- Silné korupční klima - v oblasti, kde je korupce tradičně akceptovanou formou chování lidé inklinují k páchání podobných trestných činů.

- Politická kultura - znovuzvolení zkorumpovaných politiků a neexistence kolektivních protestních akcí namířených proti korupci dodává zkorumpovaným veřejným činitelům pocit neomezených možností zneuživat svůj úřad.

- Klientelismus - zvyk vyřizovat záležitosti prostřednictvím sítě známých a rodinných příslušníků také reprezentuje podněty ke korupčnímu chování.

- Chudoba - nízké platy úředníků snižují obavy ze ztráty jejich zaměstnání a povzbuzují je k vedlejším nekalým výdělkům.

- Korupční vzory - čím více budou lidé přesvědčení, že veřejní činitelé i ostatní lidé jsou zkorumpovaní, tím náchylnější budou ke korupčnímu chování i oni sami.

- Kult rychlého zbohatnutí - ve společnosti, kde panuje představa, že je správné rychle zbohatnout, chápou tuto představu někteří lidé tak, že je nutné zbohatnout i za cenu vlastního zkorumpování.

\subsection{Podmínky podporující korupci}

Mezi základní důvody, které posilují korupční jednání patří koncentrace politické moci a rozhodování, kde rozhodující vliv ve státě mají uzavřené a politické kliky. Také centralistické, totalitní a obecně nedemokratické režimy platí za velmi zkorumpované politické systémy. Na druhé straně podporuje toto zločinecké fungování ve veřejné správě apatická společnost, která se nezajímá o politiku nebo nemá patřičný vliv. To vše souvisí se slabým právem a nedostatečnou justicí, která slouží jen mocným a vlivným lidem k prosazování jejich vlastních zájmů. Korupci podporuje rozšiřrené utajování informací, centralistické tajné rozhodování, nedostatek otevřenosti a transparentnosti. Neefektivní alokaci zdrojů způsobují velké a nekontrolované částky, které jsou určeny na financování veřejných či soukromých projekti̊. Diskutabilní podmínkou korupce je počet špatně placených úředníků a dalších zaměstnanců veřejné správy.

\subsection{Důsledky korupce}

Projevy korupce způsobují korozi občanských ctností a důvěry v právní stát. Demobilizují a demotivují široké vrstvy obyvatelstva. Korupce ohrožuje hospodářskou soutěž a tím může i ohrozit stabilitu státu. Korupce vytváří paralelní mocenské struktury, které nemají demokratický původ, a tím ohrožuje základní principy demokratického státu, nebo distribuce moci může jejich prostřednictvím probíhat na základě jiných než ústavních kritérií. Korupce je nástrojem organizovaného zločinu $\mathrm{k}$ jeho etablování ve veřejné správě a ve společnosti. Korupce ohrožuje vlastnická práva, vládu, práva a pohnutky k investování a tím ohrožuje samotný hospodářský a politický rozvoj.

Nejzávažnějším dopadem korupce ve státní správě je bezpochyby oslabení správy veřejných věcí a politiky, které může v extrémním př́ípadě vést až k rozpadu státu. Ekonomickým důsledkem je oslabení hospodářských výsledků a celé ekonomiky, což může způsobit až nemožnost podnikat, růst chudoby a nezaměstnanosti. Finanční úniky vedou k nedostatku peněz v rozpočtu státu, krajů a obcí a mohou vyvolat růst daní. Důsledky korupce mohou zasáhnout také psychickou stránku obyvatel a vyvolat rostoucí nedůvěru v politiku, 
ekonomiku, a k vlastním schopnostem. Výsledkem může být obecně rezignace a odchod těch schopných tam, kde se mohou uplatnit.

Z odhadů vyplývá, že korupce snižuje celkový hrubý domácí produkt (HDP) o 10 až 20 procent. Tato ztráta je většinou kompenzována zvýšeným daňovým zatížením obyvatel.

\section{Korupce a právní řád}

Problematika korupce a její postihování je upravena českým právním řádem ve dvou rovinách. První rovinou je oblast veřejnoprávní, kterou postihují normy trestního zákoníku. Trestní zákoník obsahuje vymezení čtyř skutkových podstat trestných činů: zneuživání pravomoci veřejného činitele, přijímání úplatku, podplácení a nepřímé úplatkářství. V určitých případech může být korupční chování kvalifikováno též jako trestní čin podvodu. Druhou rovinou je oblast soukromoprávní, kterou upravují normy obchodního zákoníku.

\subsection{Korupce a její postih v trestním zákoně}

Pojem korupce není v českých trestně právních normách definován jako samostatný trestný čin. Jsou to trestné činy uvedené v hlavě třetí zvláštní části trestního zákona, nazvané jako „trestné činy proti pořádku ve věcech veřejných“. Zejména oddíl třetí této hlavy „úplatkářství“ obsahuje v sobě trestné činy, které v sobě nesou všechny znaky korupce. Jde o tyto trestné činy: $\S 160$ přijímání úplatku, $\S 161$ podplácení, $\S 162$ nepř́mé úplatkářství a § 163 trestního zákona jako zvláštní ustanovení o účinné lítosti. Kromě úplatkářství je v našem právním řádu zakotveno několik dalších skutkových podstat trestného činu, které definují korupční chování. Protože rozhodující prostor a hlavní nebezpečí korupce leží nepochybně v oblasti veřejné správy v širším smyslu, včetně moci zákonodárné a soudní, jde především o vybrané trestné činy veřejných činitelů dle druhého oddílu třetí hlavy zvláštní části trestního zákona - zneuživání pravomoci veřejného činitele (§ 158) a maření úkolu veřejného činitele $\mathrm{z}$ nedbalosti (§ 159). K trestným činům, které mají znaky korupčního chování, lze řadit také trestné činy porušování předpisů o nakládání s kontrolovaným zbožím a technologiemi podle $\S 124 a$, porušení povinnosti v řízení o konkursu podle $\S 126$, porušování povinnosti při správě cizího majetku podle $\S 255$, zneužívání informací v obchodním styku podle $\S 128$, pletichy při veřejné soutěži a veřejné dražbě podle $\S 128 \mathrm{a}$ až 128c trestního zákona a některé další skutkové podstaty obsažené v hlavě druhé zvláštní části trestního zákona.

\section{Praxe}

Rovněž ředitel střední školy je při rozhodování o přijímání uchazečů na střední školu veřejným činitelem. Proto naplní znaky trestného činu zneužívání pravomoci veřejného činitele, jestliže přijme uchazeče na střední školu, i když uchazeč nesplnil podmínky pro přijetí na střední školu stanovené př́íslušnými předpisy.

Za zneužívání pravomoci veřejného činitele bylo posouzeno též jednání člena závodní stráže, účastnícího se v době výkonu služby rozkrádání materiálu z podniku, který měl střežit, a to tím způsobem, že ve dvou případech pomáhal nakládat materiál odcizovaný jinými osobami v ceně 16100 Kčs, dával pozor, aby spolupachatelé nebyli vyrušeni, a sám si při tom přivlastnil věc v ceně 250 Kčs.

Za přípravu trestného činu zneuživání pravomoci veřejného činitele bylo považováno jednání obviněné, která se neúspěšně pokusila navádět náčelníka $\mathrm{OO} \mathrm{VB}$, aby krev odebra- 
nou jejímu manželovi $\mathrm{v}$ souvislosti s řízením motorového vozidla vyměnil a na zjištění množství alkoholu v krvi odeslal zkumavku s krví jiné osoby.

Soud posoudil jednání celní kontrolorky, která za úplatek neproclila zboží v ceně 41035 Kčs, zasílané do ČSFR německým obchodníkem, a svým jednáním přispěla ke zkrácení cla o 10855 Kčs, jako trestný čin zneužívání pravomoci veřejného činitele.

Jako trestný čin bylo posouzeno i jednání náčelníka vojenského útvaru, který zneužíval své funkce tím, že používal bez povolení a bez náhrady nákladní auta a jinou techniku vojenského útvaru, jakož i vojáky základní služby k pracím na stavbě svého rodinného domku.

Veřejný činitel, který s úmyslem způsobit jinému škodu anebo opatřit sobě nebo jinému neoprávněný prospěch překročí svou pravomoc, se nemůže stát beztrestným jen proto, že nadř́zený orgán, do jehož pravomoci jinak věc patří, dodatečně jeho jednání schválí anebo s ním vysloví souhlas nadřizeného orgánu s jednáním veřejného činitele nepřihází vůbec $\mathrm{v}$ úvahu. Veřejný činitel, který by např́iklad dal svévolně zaplatit svoji dovolenou z prostředků orgánu, jehož je pracovníkem, by se nestal beztrestným, kdyby toto jeho jednání bylo následně schváleno jeho seřízeným orgánem, $v$ jehož pravomoci je udělování odměn. Takovýto souhlas nebo schvální je možno popř́padě uvažovat jen za skutečnost, která zmírňuje stupeň nebezpečnosti činu pachatele pro společnost, a jedná se pouze o polehčující okolnost.

\section{Př́íklady korupce v České republice}

\subsection{Kauza letištních zakázek}

Útvar pro odhalování korupce a finanční kriminality navrhl obžalovat několik bývalých vysokých důstojníků armády z korupce. V letech 1997 až 1999 měli obvinění, většinou plukovníci a podplukovníci, zmanipulovat veřejné zakázky za 482 miliónů korun. V září roku 1999 bylo obviněno osm lidí kvůli nevýhodným armádním zakázkám z porušování povinností při správě cizího majetku. V letech 1997 a 1999 měli neoprávněně využít možnosti oslovit jednoho zájemce při veřejné obchodní soutěži. V roce 2000 byli obviněni jeden bývalý a tři vysocí důstojníci z obcházení výběrových řízení a zadávání velkých zakázek předem dohodnutému zájemci. Jednou z firem, které měly neoprávněně získat armádní zakázku, byla společnost Bohemia T.T.W. V únoru 2001 šla tato firma do konkurzu. V květnu 2002 vyšetř̌ování skončilo návrhem na postavení devíti bývalých zaměstnanců ministerstva obrany a dvou podnikatelů před soud za porušování pravidel hospodářského styku. Zakázky za 482 miliónů korun podle obžaloby dostala vždy stejná soukromá firma. Avšak již září 2002 Městský soud v Praze stíhání zastavil a žalobci vrátil jeho návrhy k došetření. Žalobce podal proti usnesení stížnost k vrchnímu soudu. Kauza se dále prodlužovala. V prosinci téhož roku Vrchní soud definitivně vrátil prŕípad policii a státnímu zástupci $\mathrm{k}$ došetření. 5. března 2007 Policie ČR znovu navrhla obžalovat 11 lidí z korupce a manipulace s veřejnými zakázkami na úpravy letiš a opravy letištní techniky.

„V této kauze je skončeno vyšetřování a my jsme státnímu zastupitelství podali návrh na obžalování bývalých důstojníků Armády ČR pro trestné činy porušování závazných pravidel hospodářského styku a podplácení,“ uvedla Veronika Dumková, vrchní komisařka Útvaru pro odhalování korupce a finanční kriminality. Obvinění se měli dopustit trestné činnosti v souvislosti se zadáváním veřejných zakázek.

Fungovalo to tak, že nejdříve došlo k realizaci zakázek, které provedly dvě společnosti, a to dříve, než s nimi byly uzavřeny smlouvy o provedení nebo než proběhlo výběrové rí- 
zení. Návrh žaloby se vztahuje i na dva zástupce společností a jednoho občanského zaměstnance armády. V čele jednoho podniku se sídlem v Moravskoslezském kraji stál podle dřivějších informací bývalý voják z povolání. Za porušování závazných pravidel hospodářského styku jim hrozí dva roky vězení, za podplácení může soud uložit až pětiletý trest.

Policie musela nechat v př́ípadu zpracovat nový posudek, protože během vyšetřování se změnil zákon o zadávání veřejných zakázek. Vyšetřovatelé potřebovali zjistit, zda není pro podezřelé příznivější. Podle policie šlo o veřejné zakázky na stavební úpravy letiš , na opravy letištní techniky a na opravy techniky letištního zabezpečení. Důkazy o manipulaci se zadáváním zakázek byly zjištěny i z materiálů ministerstva obrany, nebo obvinění naprríklad již na jaře umožnili provést ve vojenských objektech stavební práce a na konci roku pak provedli „výběrové rrízení" na dodavatele těchto prací. Ministerstvo obrany rídili v letech 1997 až 1999 celkem tři ministři, Miloslav Výborný (KDU-ČSL), Michal Lobkowicz (Unie svobody) a Vladimír Vetchý (ČSSD).

http://www.novinky.cz/domaci/

\subsection{Korupce na ministerstvu dopravy}

Korupční tendence se dají najít téměř na každém ministerstvu. Pro příklad uvádím kauzu „bioetanol“ na ministerstvu dopravy. Po zatýkání na ministerstvu dopravy v březnu 2006 policejní komisař Útvaru pro odhalování organizovaného zločinu (ÚOOZ) Pavel Hruška ze sedmi zadržených obvinil z korupce šest podezřelých. Podle obvinění chtěli úplatky ovlivnit rozhodování státních úředníků na ministerstvech dopravy a zemědělství, aby získali výhody při výrobě bioetanolu a získání investičních akcí na své pozemky. $\mathrm{V}$ jednom př́ipadě měl být podplacen policista, který však věc oznámil a pachatel padl do připravené pasti. Bylo obviněno šest osob. O posledním sedmém podezřelém policejní komisař rozhodne později.

Nabízené úplatky se pohybovaly okolo jednoho miliónu korun. Okruh podezřelých a další zatýkání v souvislosti s podplacením spojeným s programem bioetanol a přidáváním této látky do benzínu je údajně spjato s aktivitami nejmenovaného kolínského lihovaru.

http://www.chladas.estranky.cz/clanky/aktualne/

\subsection{Uplácení bývalého poslance PS Parlamentu ČR a radního Prahy 10}

Policejní komisař Útvaru odhalování korupce a finanční kriminality služby kriminální policie a vyšetřování dne 14. 9. 2006 navrhl obžalovat bývalého poslance Poslanecké sněmovny Parlamentu ČR pro účastenství formou pomoci k trestnému činu přijímání úplatku dle ustanovení § 10/1c) trestního zákona k ustanovení § 160/2,4b) trestního zákona a radního Městské části Praha 10 pro trestný čin přijímání úplatku dle $\S 160 / 2,4 b)$ trestního zákona.

Trestní jednání obviněných spočívá v tom, že tehdejší poslanec po vzájemné předchozí dohodě s radním Městské části Praha 10, který byl zároveň předsedou komise územního rozvoje Městské části Praha 10, v období od měsíce listopad 2004 do měsíce březen 2005, požadovali za ovlivnění rozhodnutí Ưřadu městské části Praha $10 \mathrm{v}$ rámci správního řízení o povolení změny v užívání stavby týkající se prodloužení dočasného užívání autobazaru a dočasného provozování tržiště, úplatek ve výši 800 000,- Kč. V případě prokázání viny jim může soud za uvedené jednání uložit až osmiletý trest odnětí svobody.

http://www.mvcr.cz/zpravy/2006/ 


\subsection{Privatizace podniku Čokoládovny Praha}

Podnik se privatizoval v první vlně kuponové privatizace pole projektu, který schvaloval prodej 46\% akcií švýcarské firmě Nestlé, 15\% šlo do Europen Bank for Restructuring and Development (EBRD) a 35\% šlo na kuponovou privatizaci. Cena za 1045185 akcií, ketré měly přímoprodat Nestlé a EBRD byla ve výši 3119 Kč za akcii. V dřivějším návrhu se měly některé akcie prodat také První investiční, a. s. (PI), tj. investičnímu a privatitizačnímu fondu ve vlastnictví Investiční banky (IB), za stejnou cenu jako v př́padě dalších kupujících. Ale v privatizační metodě schválené vládou dne 8. 1. 1992 nebyla vůbec žádná zmínka o PI.Přesto prodal Fond národního majetku 88079 akcií První investiční, a. s. za jejich nominální hodnotu 1000 Kč za akcii. dalším rozdílem oproti schválenému projektu bylo, že Nestlé a EBRD dostaly 1459610 akcií za cenu 2233 Kč za jednu akcii. Tímto způsobem získala PI akcie, které v dubnu 1994 měly hodnotu 7,5 krát vyšší než byla cena, kterou za ně PI zaplatila. Tomáš Ježek, bývalý ministr pro privatizaci a předseda FNM v době skandálu okolo Čokoládoven Praha prohlásil, že celá věc byla „blbá, nejapná a pitomá administrativní chyba“. NKÚ provedl následně audit privatizace a zjistil, že prodej akcií byl protiprávní, protože FNM neprovedl privatizaci podle schváleného projektu. Privatizace Čokoládoven Praha způsobila škodu ve výši 8,8 milionu Kč. Výsledkem kauzy nebylo soudní ř́zení, ale politický boj mezi předsedou FNM Tomášem Ježkem a ministrem pro privatizaci Jiř́m Skalickým. Nakonec Ježek rezignoval, ale policejní vyšetřování ve finále nepřineslo žádníe výsledky.

Frič P. a kol.: Korupce na český způsob. 1999, s. 185-187.

\section{Transparency International}

Transparency International (TI) je mezinárodní nezisková nevládní organizace bojující proti korupci, kterou definuje jako zneužití postavení k vlastnímu prospěchu. TI také podporuje změny $\mathrm{k}$ větší integritě v hospodářství, politice a společnosti. Vznikla v roce 1993 jako nezisková organizace se sídlem v Německu. Spolu s dalšími ji založil Peter Eigen, bývalý vyšší funkcionár Světové banky. Dnes funguje jako sdružení více než 80 národních poboček, řízených mezinárodním sekretariátem v Berlíně.

TI vydává každoroční žebříček o stupni korupce v jednotlivých zemích - Corruption Perception Index. Tento žebříček je kritiky považován za neobjektivní, nebo je založen na výzkumech veřejného mínění, které popisují pouze subjektivní dojmy, nikoli fakta. Podle kritiků je již samotná idea porovnání korupce v různých zemích problematická, nebo definice korupčního jednání se $\mathrm{v}$ různých jurisdikcích liší. TI na takové kritiky odpovídá, že používá vědeckých metodik komparatistiky, tak jak ji vyvinuly během posledního půlstoletí renomované instituty po celém světě. Dále, že jde právě i o to, korupci měřit stejnými měřítky, a zejména o to, spojit síly k prosazení integrity.

Srovnání hospodářské konkurenceschopnosti jednotlivých zemí a stupně jejich integrity Competitiveness and corruption, bylo poprvé představeno na konferenci Corruption how and why to avoid it koncem roku 1998 v Praze.

Citováno z „http://cs.wikipedia.org/wiki/Transparency_International““

\subsection{Index vnímání korupce}

Od roku 1995 se používá pro srovnání tzv. index vnímání korupce (Corruption Perception Index - CPI). Měření míry korupce ve státě je velmi obtížné, jelikož nelze srovnávat úroveň korupce podle explicitních měřitelných dat (např. počet zatčených nebo počtu soudních případů). Taková data spíše vypovídají o vůli a schopnosti státu korupci odhalo- 
vat a potírat. Proto se používá metoda subjektivního vnímání korupčního prostředí mezi podnikateli, analytiky, státními úředníky apod.

Výběr států dle umístnění v žebř́ičku CPI

\begin{tabular}{|c|l|c|c|c||}
\hline \multirow{2}{*}{ Rok } & \multirow{2}{*}{ Země } & \multirow{2}{*}{ CPI } & \multicolumn{2}{c|}{ Pořadí země } \\
\cline { 4 - 5 } & & & na světě & v EU \\
\hline \hline 2004 & Finsko & 9,7 & 1 & 1 \\
\hline & Velká Británie & 8,6 & 11 & 5 \\
\hline & Rakousko & 8,4 & 13 & 6 \\
\hline & Francie & 7,1 & 22 & 11 \\
\hline & Slovinsko & 6 & 31 & 21 \\
\hline & Recko & 4,3 & 49 & 22 \\
\hline & Česko & 4,2 & 51 & 23 \\
\hline \multirow{2}{*}{2005} & Slovensko & 4 & 57 & 2 \\
\hline & Finsko & 9,6 & 2 & 8 \\
\hline & Rakousko & 8,7 & 10 & 12 \\
\hline & Velká Británie & 8,6 & 11 & 19 \\
\hline & Francie & 7,5 & 18 & 24 \\
\hline & Slovinsko & 6,1 & 31 & 24 \\
\hline & Česko & 4,3 & 47 & 24 \\
\hline & Řecko, & 4,3 & 47 & 47 \\
\hline
\end{tabular}

www.transparency.cz

\section{Korupce v ČR podle Světové banky}

V roce 2006 vydala Světová banka výsledky studie o korupci v oblastech, kde se protínají soukromé aktivity se státními: „Anticorruption in Transition 3-Who is Succeeding ... And Why? "Studie staví na rozhovorech se zástupci více než 20000 podniků. Ve zprávě je hodnoceno období 2002-2005. Analyzuje vývoj ve 26 bývalých socialistických zemích a v Turecku, pro srovnání sleduje i pět zemí „staré“ EU: Německo, Řecko, Irsko, Portugalsko a Spanělsko.

Jak jsem uvedl na začátku, z regionu střední a východní Evropy se u nás nejlépe vede úplatkářství v oblasti veřejných zakázek. Jsme jediná nová členská země EU, kde korupce nejenže neklesá, ale naopak významně roste. České společnosti průměrně odvedou na úplatcích 0,6 \% svých tržeb. Středně velká firma s ročními tržbami kolem 1 miliardy Kč tak ročně na úplatky použije 6 miliónů Kč. Největší firmy s tržbami počítajícími se na desítky miliard Kč, na úplatky vydají až stonásobně víc.

Podle studie Světové banky vykazují postkomunistické země zlepšující se výsledky v boji s korupcí, avšak Česká republika silně pokulhává. Hưře než Česká republika si ze sledovaných zemí vedou již jen Albánie a Litva. Největšího zlepšení přitom dosáhly Gruzie a Slovensko, kde bývalá vláda prosadila programy ekonomických a institucionálních reforem a úplatkářství významně kleslo. 
Dobrou zprávou, a to i pro Českou republiku, je snížení frekvence používání úplatků. Konkrétně toho, jak často manažeři firem používali „neoficiální platby“, aby dosáhli žádoucího výsledku. Přestože tato statistika mezi roky 2002 a 2005 klesla i u nás, až tak se zase radovat nemůžeme. Je zajímavé, že české firmy sídlící ve velkých městech používají úplatky méně často než podniky v menších českých městech.

Procento ročních př́ijmů, které firmy použijí na úplatky se u nás mírně snížilo, ale opět ze s námi srovnatelných zemí nejvíce kleslo na Slovensku. Podle výpovědí českých firem stále rostou také požadavky na úplatky vyžadované vládními institucemi v ČR.

Anticorruption in Transition 3-Who is Succeeding ... And Why? http://web.worldbank.org/WBSITE/EXTERNAL/NEWS/0

\section{Boj s korupcí}

\subsection{Anonymní linka CERD}

Ve snaze pomoci zlepšovat morální prostředí v České republice funguje u nás linka CERD (Centrální registr dlužníků České republiky). Anonymní linkou můžou občané podat podnět k prošetření jakéhokoliv podezření na nekalé jednání jedinců či organizovaných skupin. Pokud jste se dozvíme, nebo jsme dokonce byli přímými účastníky či svědky takového jednání, mámo možnost vyplnit jakýsi formulář podle toho, které sféry se záležitost týká.

Poskytnutá informace bude automatizovaně předána příslušným orgánům $\mathrm{k}$ prošetření. IP adresa připojení není jakkoliv archivována, ani jinam předávána. Zachování anonymity je zajiš ováno $z$ důvodu ochrany oznamovatele před možným ohrožením ze strany dotčených osob, společností, úřadů a institucí.

Zaslané podněty budou s časovým prodlením předány médiím a tím celé veřejnosti ke kontrole, jak bylo s danou informací naloženo. Jedině veřejná kontrola občanů je schopna donutit př́slušné orgány $\mathrm{k}$ řádnému prošetření záležitosti a vyvození odpovídajících závěrů.

\section{K dispozici jsou dva formuláře oznámeni:}

1. Státní sféra - (úředníci, zastupitelé, politici, policisté, atd.) https://www.dluznik.cz/korupce-statni-sfera.php

2. Soukromá sféra - (občan nepodnikatel, občan podnikatel, manager firmy, atd.) https://www.dluznik.cz/korupce-soukroma-sfera.php

\section{Př́́klad (názorná ukázka):}

Podezření na nekalé jednání by mělo obsahovat konkrétní popis skutečností, které se odehrály či právě probíhají. Poskytnuté informace mohou být i z neověřených zdrojů. Dále lze poskytovat informace o osobách dosahujících značných př́ijmů a majetků, které nekorespondují s jejich oficiálním příjmem, např. podnikatel vlastní několik luxusních vozů, nemovitosti a přitom je jeho firma ve značné ztrátě či dokonce v konkursu, nebo úředník s platem 15.000,- Kč čistého vlastní majetek těmto př́immům neodpovídající (luxusní vůz, nemovitosti apod.). 
V př́ipadě poskytnutí důležitého anonymního svědectví, je totožnost lidí, kteří kontaktovali linku CERD, plně chráněna a nelze ji jakkoliv dohledat. Podaná oznámení jsou vedena jako podezření z trestního jednání a tudíž i v př́ípadě neověřené informace, se tito lidí nevystavují riziku křivého obvinění.

http://www.dluznik.cz/korupce.php

\subsection{Vládní program boje proti korupci}

Usnesením č. 125 ze dne 17. února 1999 vzala vláda na vědomí Vládní program boje proti korupci a uložila členům vlády a vedoucím ústředních správních orgánů úkoly, jejichž plnění by mělo zabránit rozmachu korupčního jednání ve společnosti.

Jediným možným řešením je nastoupení „ozdravné kúry“, kterou musí absolvovat jak instituce státního aparátu, tak i veřejnost sama. Pokud jde o priority v boji s korupcí, úkoly vyplývající z Vládního programu boje proti korupci jsou zaměřeny zejména na potírání korupce ve veřejném sektoru. Za obzvláš závažnou program označuje korupci vedoucích pracovníků ústředních orgánů státní správy, soudců, státních zástupců, policistů, celníků, zaměstnanců finančních úřadů a státních kontrolních institucí. Tato korupce je pro stabilitu státu nejnebezpečnější a mohla by podle programu též představovat brzdu efektivního postupu proti dalším formám korupce a protiprávního jednání vůbec.

\section{Zásadním opatřením v boji proti korupce ve státní správě je vytvoření:}

- fungujícího systému kontroly, který poskytne objektivní informace, na jejichž základě lze přrijmout účinná opatření k nápravě;

- komplexní a vnitřně konzistentní legislativy, včetně jasně formulovaných a dodržovaných sankcí. Řešení korupce nemůže spočívat pouze v oblasti trestního práva. Přestože ve společnosti je všeobecná znalost o rozšířenosti korupce, doložených trestných činů spojených s korupcí je málo. Poměr latentní a odhalené kriminality u korupce je jednoznačný ve prospěch latentní;

- stabilní, kvalifikované státní správy, která bude mít autoritu v očích veřejnosti. V rámci legislativních úprav je třeba provést úpravu státní (veřejné) služby se současným přijetím úpravy ochrany společnosti před nevhodným jednáním pracovníků státní služby.

Vládní program boje proti korupci se opírá o potřebné změny legislativy a důležitá organizační opatření (např. formulování a dodržování Kodexu etiky zaměstnanců ve veřejné správě, etického kodex policisty; větší efektivita činnosti protikorupční komise Ministerstva vnitra...). Tato koncepce počítá $\mathrm{s}$ vlivem na oblast vzdělávání a mediálního působení (školení policistů, soudců; semináře; Příručka občanské obrany proti korupci; ...). V boji proti korupci se chce ministerstvo vnitra využít široké mezinárodní spolupráce (Rada Evropy, Evropský úřad boje proti podvodům OLAF, Organizace spojených národů, mezinárodní policejní spolupráce, ....).

\subsection{Chystané změny ministerstva spravedlnosti}

Ministr spravedlnosti Jiří Pospíšil chce zvýšit tresty za korupci. Přiměla jej k tomu, mimo jiné, kritika za zahraničí, která považuje tresty za korupční chování za nedostatečné. Horní hranice trestu se zvýší o třetinu až polovinu. Zatímco nyní si ten, kdo bere úplatek, mohl odnést maximálně osmiletý trest, nově to bude až o čtyři roky více. I když jde zdánlivě jen o výši trestu a samo o sobě to nízký počet odhalených případů nezvýší, bude tato skutečnost mít alespoň odstrašující efekt. Tresty jsou u nás totiž v současnosti tak nízké, že i při prokázané korupci to téměř vždy končí podmínkou. V České republice je zatím ročně za prrijímání úplatku odsouzeno v průměru třicet lidí. Ze 158 odsouzených za posledních pět 
let jen jediný úředník skočil za mřížemi. Zbytek dostal peněžitý či podmíněný trest. Za nabízení úplatku bylo odsouzeno 423 lidí, z toho desetina nepodmíněně. To, že korupce je trestána málo, ukazuje i kauza „pět v českých“, kdy nyní hrozí dvanáctileté vězení hlavnímu aktérovi př́ípadu, tajemníkovi expremiéra Grosse Zdeňku Doleželovi. Jenže ne za korupci, ale za podvod. Za stejný čin, ohodnocený jako korupce, by mu hrozilo pět let. Korupce jako podvod vůči státu by měl být trestán stejně. Novela zákona, kterou vypracovalo ministerstvo spravedlnosti, rovněž stanoví, že neoznámení korupce bude nově též trestným činem a soudy budou muset také uložit trest zákazu činnosti. Novela by podle ministra Pospíšila mohla začít platit od začátku příštího roku.

\begin{tabular}{||l|c|c|c|c|c|c|c|c|c|c||}
\hline & \multicolumn{10}{|c|}{ Odsouzení } \\
\cline { 2 - 12 } & \multicolumn{3}{|c|}{ za přijímání úplatku } & \multicolumn{6}{c||}{ za podplácení } \\
\hline \multicolumn{1}{|c|}{ Rok } & $\mathbf{2 0 0 2}$ & $\mathbf{2 0 0 3}$ & $\mathbf{2 0 0 4}$ & $\mathbf{2 0 0 5}$ & $\mathbf{2 0 0 6}$ & $\mathbf{2 0 0 2}$ & $\mathbf{2 0 0 3}$ & $\mathbf{2 0 0 4}$ & $\mathbf{2 0 0 5}$ & $\mathbf{2 0 0 6}$ \\
\hline \hline elkem & 31 & 28 & 31 & 38 & 30 & 124 & 66 & 90 & 93 & 50 \\
\hline Nepodmíněně & 1 & 0 & 0 & 0 & 0 & 11 & 4 & 6 & 8 & 7 \\
\hline
\end{tabular}

Jindřichohradecký deník, 6. dubna, str. 3

\section{Shrnutí}

Ze sociologického šetření společnosti GfK Praha ze září loňského roku vyplynulo, že $56 \%$ populace považuje úplatky za běžnou součást života. Toto ohromné číslo má z následek, že je Česká republika v rámci EU trvale řazena mezi státy s nejvyšší mírou korupce (dle hodnocení Transparency International - září 2005). Česká republika je na 1. místě v regionu střední a východní Evropy co se týče růstu korupce v oblasti zadávání veřejných zakázek (dle studie Světové banky - červenec 2006). Podle žebříčku Indexu vnímání korupce (CPI), který pravidelně sestavuje nevládní organizace Transparency International, leží Česko pro rok 2005 společně s Řeckem, Namibií a Slovenskem na 47. - 50. místě.

Hlavní příčiny vysoké míry korupce v ČR tkví v silném mocenském monopolu státní správy, nekontrolovatelném rozsahu možností mocenského rozhodování a v obecně nízké úrovni veřejné kontroly. Nejdůležitějšími principy boje proti korupci by měla být prevence, dokonalá průhlednost aktivit veřejných činitelů a tvrdý nekompromisní postih. Čím méně stát rozhoduje o životech občanů, tím menši je potřeba někoho korumpovat. Vhodným krokem by byla minimalizace státních regulací a zásadní zjednodušení legislativy. $\mathrm{Na}$ ministerstvech a obecně úřadech by mělo dojít k zeštíhlení rozpočtů a ke snížení prostředků přerozdělovaných státem. Jistě by pomohla důsledná debyrokratizace státní správy a omezení počtu zvláštních procesních pravidel. V současnosti je poměrně rozšířená medializace korupčního jednání, ale lidé jsou těmito kauzami spíše otrávení a veřejné odsouzení př́padů korupce se děje jen s povzdychem u televizní obrazovky. Skutečné veřejné „pranýřování“ provádějí pouze novináři. Když pak dotyčný tento žurnalistický vichr přestojí, má většinou vyhráno.

Koncepce vymýcení korupce z české kotliny by mělo každopádně obsahovat zprůhlednění systému zadávání veřejných zakázek, zprůhlednění systému čerpání prostředků z veřejných rozpočtů a zvýšení transparentnosti rozhodování veřejné správy. Veřejná kontrola nad činností veřejných funkcionářu a jejich majetkoprávními poměry po dobu výkonu funkce je stále diskutovanou kapitolou. Zejména přiznávání majetku je poměrně ošemetná věc, která rozčiluje např́íklad politiky a dle mého názoru v podstatě nic neřeší. Kdo může politikovi dokázat, že si nenašetřil velký balík peněz z předchozího zaměstnání ještě před 
uvedením do státní funkce atd. Dobrou myšlenkou je samozřejmě zřízení jednotné protikorupční linky, kam by lidé podle vzoru linky CERD mohli vznášet pochybnosti o původu majetku veřejných činitelů či informovat o podezření z korupčního jednání u daných osob.

Jak již pan ministr spravedlnosti Jiří Pospíšil uvedl, je nutno s korupcí zatočit nejexplicitnějším prostředkem, a sice zpř́ísněním trestů v trestním zákoně a úpravou zákona o střetu zájmů. Rukou v ruce by měla jít vymahatelnost práva. Tudíž nejen zvýšení trestní sazby, ale také její využívání by mělo vést k odstrašení potenciálních korupčníků. Jim by měla být spolu s trestem odnětí svobody a peněžního trestu zakázána účast na veřejných zakázkách okamžitě při jakýchkoliv pochybností z úplatkářství apod.

Rozhodně bych byl pro zavedení principu odpovědnosti veřejných funkcionářů při správě majetku tak, jako platí pro členy orgánů obchodních společností. Ten, kdo způsobí škodu, bude za ni ručit celým svým majetkem.

Další návrh, který by pomohl s katastrofálním stavem v Česku by bylo zřízení specializovaných justičních orgánů se zaměřením na korupci.

\section{Jak řeší korupci v zahraničí?}

- Německo - daňový úředníci jsou povinni vstrrícně informovat státní zástupce o podezření z korupčního jednání konkrétních fyzických nebo právnických osob. Trestně postižitelná je korupce provedená v zahraničí a vztahující se k německému subjektu.

- Řecko - navržen zákaz zaměstnávání bývalých státních úřredníků (bezprostř̌edně po odchodu za státní služby po několik let) ve firmách, které nabízejí své produkty té části veřejného sektoru, v níž byli zaměstnáni.

- Mad'arsko - ohlašovací povinnost vládních úředníků při podezření na korupční jednání v jejich okolí.

- Slovensko - možnost nasazovat policejní agenty „provokatéry“ při podezření z úplatkářství.

- Litva-zvýšení platů celníkům, kteří mají obecně velkou příležitost k přijímání úplatků.

\section{Závěr}

Lidé v České republice začali vnímat korupci jako něco, co sice není morálně správné, ale musí se udělat pro dosažení jejich cílů. Někteří lidé zastávají názor, že úplatky musí být dány už proto, aby úředník či jiná státní osoba vykonala vůbec to, co má ze zákona pro občany činit. Lidé často přiznávají, že na úřady, do nemocnice a další místa chodí preventivně $\mathrm{s}$,malou pozorností“", aby věc, v jejímž zájmu přišli, byla opravdu vyřízena.

Z výsledků nevládní organizace Transparency Intrernational jednoznačně vyplynulo, že se Česko posouvá v žebřričku korupčních zemí níž a níž. Přijde-li v budoucnu obrat, to je otázka. Ministerstvo vnitra začalo tuto otázku řešit, ale situace se nelepší. Svá doporučení jsem uvedl ve shrnutí. Nejsem právník a nemám zkušenosti s fungováním velkých úřadů a ministerstev, ale jakékoliv rychlé a striktní řešení komplikované situace je nevyhnutelné. Ovšem jen za předpokladu, že k tomu bude všeobecná vůle. Někdy mám spíše pocit, že značnému počtu lidí současný chaos v právním řádu a možnost korumpování veřejných činitelů vyhovuje. Např́iklad stará paní, která trpí bolestí kyčelního kloubu ráda zaplatí např. 50000 Kč panu doktorovi za to, že jí protlačí v pořadníku čekatelů na výměnu kyčelního kloubu. Uleví sice peněžence o danou částku, ale je ráda, že nebude muset v bolestech čekat na výměnu několik let. Pan doktor ale nesmí požadovanou částku šroubovat na vysokou úroveň. Pak by se mohla stará paní urazit a na pana doktora podat trestní oznámení. Ve 
velké míře tedy dochází ke korupci jen u osob, které se důvěrně znají a vědí, co mohou od sebe očekávat.

Zajímavá je myšlenka slovenského ministerstva vnitra, která počítá s nasazením agenta „provokatéra“. Je dobrý nápad, ale vede k tomu, že lidé mají obecně špatný pocit z toho, že je policejní složky sledují (jako v minulém režimu) a snaží se je dostat do problémů. Podle mého názoru by agent ,provokatér“ nemusel být vždy efektivní. Úředníci by nemuseli vždy sednout agentovi na lep, protože by jim tento pro ně neznámý člověk, který by je žádal o provedení čehosi za úplatu, přišel podezřelý. Je zde i možnost, že by se sám agent provokatér mohl dopouštět korupční činnosti.

Velkým problémem je dokazování korupčního jednání. Obecně se dá říci, že pokud policie nechytí pachatele př́imo při činu, když přebírá obálku s penězi, nemá velkou šanci obviněného usvědčit. Odposlouchávání obviněných je dnes častým jevem. Osobně se mi tato praktika nelíbí, protože narušuje osobní svobodu a často se míjí účinkem. I v př́ipadě videí natočených skrytou kamerou či zvukových nahrávek se mohou nahrané skutečnosti bohužel interpretovat i tak, že nakonec dojde k úplnému zastavení trestního stíhání.

Lidé jsou díky téměř každodenním zprávám o korupci ve státní správě, na obecních úřadech, na ministerstvech, v nemocnicích, při vyšetřování trestné činnosti, na soudech atd. unavení a otrlí. Psychologický dopad je bud' takový, že lidé chápou toto jednání jako vzor a sami se podle toho chovají - uplácejí, ř́́kají si o úplatky a za úplatu jsou schopni udělat takřka cokoliv. Tím roztáčejí korupční perpetum mobile, které pohlcuje stále více účastníků. Druhou skupinou lidí jsou „slabšíi“ povahy, kterým jejich morální standard nedovolí sklouznout $\mathrm{k}$ tomuto jednání. Tito lidé trpí depresemi a jsou z chování ostatních zoufalí a nevidí z této situace východisko.

Mým názorem je, že existuje dostatečných počet prostředků, jak s korupcí v České republice zatočit. Jen chybí odhodlání a vůle. Není možné dělat ve složitých koncepcích, jaké vydává ministerstvo vnitra, výjimky a spoléhat na nepřehledné množství zákonů a jejich novel. Poslanci a senátoři situaci neřeší komplexně a zaměřují se na menší a středně velké „ryby“ ve státních funkcích. Jak může fungovat program národního boje proti korupci, když je obviněn člen vlády z přijímání úplatku 500000 Kč? Je pochopitelné, že se předseda vlády ocitá v komplikované politické situaci, kdy má chatrnou vládu, které hrozí každý den, že jí poslanci vysloví nedůvěru. Ale jediné správné řešení je odvolat obviněného ministra za jakoukoliv cenu. Není př́ípustné dělat s tak závažnou problematikou, jako je korupce ve státní správě, kompromisy a výjimky. Oproti základním principům právní společnosti by měla platit „presumpce viny“ (viz šéf ČSSD Paroubek) a každý obviněný veřejný činitel by měl po vznesení obvinění odejít ze své funkce. Policie by měla následně príípad prošetřit a pak by se dotyčný mohl vrátit do své funkce.

To, že by se korupce u nás někdy úplně vymýtila, je naprosto naivní představa. Korupce tu bude s námi vždy, ale problém České republiky je v tom, že korupce čím dál více narušuje právní strukturu a má velké ekonomické dopady. Lidé by jí neměli chápat jako součást každodenního života. To je základní věc, o kterou by mělo jít především.

Je nutné začít od špiček. Bojovat s korupcí rázně, nekompromisně a bez výjimek. Tak zní moje představa o rychlém zlepšení situace v České republice. 


\section{Literatura}

[1] FRIČ, P. a kol.: Korupce na český způsob. Praha: G plus G, 1999. ISBN 80-86103-26-9

[2] FRIEDRICH C. J. 1972: Corruption Concepts in Historical Perspective. New Jersey: Transition Publisher, 1990

[3] KAVEREN J. van 1957: Corruption as a Historical Phenomenon

[4] NOVOTNÁ E. PR Management. J. Hradec: VŠE Praha, 2006. ISBN 80-245-1047-2

[5] NYE J. S. 1967: Corruption and Political Development

[6] POKORNÝ M.: Zvýši se tresty za úplatky. Jindřichohradecký deník, 6. dubna 2007, str. 3

\section{Vybrané paragrafy $z$ trestního zákona:}

§ 124 a) porušování předpisů o nakládání s kontrolovaným zbožím a technologiemi

§ 126 porušení povinnosti v řízení o konkurzu

§ 255 porušování povinnosti při správě cizího majetku

$\S 128$ zneužívání informací v obchodním styku

$\S 128$ a) - c) pletichy při veřejné soutěži a veřejné dražbě

$\S 158$ zneužívání pravomoci veřejného činitele,

$\S 159$ maření úkolu veřejného činitele $\mathrm{z}$ nedbalosti,

$\S 160$ přijímání úplatku,

$\S 161$ podplácení,

§ 162 nepřímé úplatkářství,

$\S 163$ učiněná lítost

Centrální registr dlužníků České republiky [online]. $<$ http://www.dluznik.cz>

Chladas stránky [online]. <http://www.chladas.estranky.cz $>$

Ministerstvo vnitra ČR [online]. $<$ http://www.mvcr.cz $>$

Novinky CZ [online]. <http://www.novinky.cz>

Světová banka [online]. <http://www.worldbank.org >

Transparency Intrernational [online]. http://www.transparency.cz 